\title{
O FENÔMENO DA ILICITUDE LUCRATIVA ${ }^{1}$
}

\section{THE PHENOMENON OF LUCRATIVE ILLEGALITY}

\author{
PEDRO RUBIM BORGES FORTES 2
}

\begin{abstract}
Resumo: O presente artigo discute o fenômeno da ilicitude lucrativa. Como as empresas privadas tomam decisões racionais sobre a violação das leis consumeristas e a observação empírica mostra que as empresas brasileiras continuam violando o
\end{abstract}

\begin{abstract}
${ }^{1}$ Este artigo foi selecionado em 2011 para o IV International Junior Faculty Forum (IJFF), então organizado pela Harvard Law School e pela Stanford Law School. Versões anteriores do texto foram discutidos na FGV DIREITO RIO, no Institute for Law and Finance (ILF) da Universidade Goethe (Frankfurt), na Harvard Law School (Cambridge), no ITAM Faculty Workshop (Cidade do México), no Seminário do GRIPS, no Nuffield College, Universidade de Oxford (Oxford), e no Colóquio do Centre for Transnational Legal Studies mantido pela University of Georgetown em Londres. Sou grato por todo o feedback recebido e já incorporado no artigo. Estou particularmente em dívida com o professor Joaquim Falcão por seu apoio à pesquisa empírica na Escola de Direito da FGV. Eu sou grato a Shunko Rojas, Antonio Porto, Marcio Grandchamp, Luis Borges, Feliciano Guimarães, Ricardo Morishita, Tobias Tröger, Agustin Barroilhet, Gisela Mation, João Paulo Ferraz Vasconcellos, Stewart Macaulay, Carol Steiker, Deborah Hensler, Rogelio Perez-Perdomo, Lawrence Friedman, Bruno Salama, Mariana Pargendler, Joyce Sakda, Virgilio Andrade, Raymundo Gama, Yvonne Salt, Aron Szekely, Dingeman Wiertz, Katharina Grabietz, Denis Galligan, Christopher Hodges, Stefan Vogenauer, Alvaro Santos, Avi Bourassa, Filiz Wölfle, Hang Xiao, Conner Pine, Gregory Reith, Giovanni Papotti, Brigid McCarthy, Elena Tan, e Luis Guillermo Rosero para ler versões anteriores e fornecer feedback extremamente útil. Anelise Jordão e Lucas Thevernard foram valiosos assistentes de pesquisa. Esse artigo foi publicado em inglês em 2015 pelo Journal of the Oxford Centre for Socio-Legal Studies e dois revisores anônimos também fizeram comentários, sugestões e críticas bastante úteis. Sou particularmente grato a Po-Hsiang Ou e Matilde Gawronski por sua excelente assistência editorial e orientação sobre como incorporar o feedback desses revisores anônimos. Obrigado também Christiane Haschka Fortes por seu incentivo e apoio com figuras e tabelas. A publicação dessa pesquisa em português foi viabilizada pelo convite do professor Carlos Bolonha para que eu organizasse um dossiê sobre a institucionalização da educação e da pesquisa jurídica para a Revista de Estudos Institucionais e eu sou extremamente grato ao eminente Diretor da Faculdade Nacional de Direito e Editor-Chefe da REI por todo o inestimável apoio. Da mesma maneira, o zelo editorial e cuidadoso trabalho do EditorExecutivo, Daniel de Souza Lucas, foi inestimável para a publicação do artigo no Brasil com a qualidade necessária. Além dos editores, a versão brasileira do texto foi beneficiada por uma cuidadosa revisão do texto feita por Júlio Machado, a partir de sua valiosa experiência acadêmica e longa atuação profissional na área de tutela coletiva do consumidor. Finalmente, devo agradecer a todos os profissionais do direito envolvidos com a comunidade de proteção do consumidor no Rio de Janeiro por gastar seu valioso tempo comigo e compartilhar seus pensamentos sobre o assunto. Sem a colaboração destes promotores de justiça, defensores públicos, juízes, membros do poder executivo e advogados da empresa, esse artigo não teria sido escrito.

2 Professor Visitante no Programa de Pós-Graduação em Direito da Universidade Federal do Rio de Janeiro (PPGD/UFRJ). Pesquisador Associado no Centre for Socio-Legal Studies da Universidade de Oxford e Promotor de Justiça no Ministério Público do Estado do Rio de Janeiro. E-mail: pfortes@stanfordalumni.org.
\end{abstract}


Código de Defesa do Consumidor (CDC), o sistema de tutela coletiva não consegue prevenir essas irregularidades devido à insuficiência de sanções. Analisando todas as 405 ações coletivas movidas contra empresas privadas pelas Promotorias de Justiça de Tutela Coletiva de Defesa do Consumidor da Capital no Ministério Público do Estado do Rio de Janeiro, entre 1991 e 2010, as sanções impostas pelos juízes não foram suficientes para prevenir novas transgressões coletivas. Os tribunais brasileiros não devem apenas condenar essas empresas por suas violações dos direitos do consumidor, mas também impor sanções econômicas e obrigá-las a reembolsar efetivamente as tarifas ilegais que cobraram de forma abusiva. Os danos punitivos devem ser ótimos, dissuadindo as empresas sem causar custos excessivos que possam prejudicar acionistas e consumidores. A ilicitude não deve ser lucrativa. No cenário atual de dissuasão imperfeita, as instituições financeiras, as empresas de telecomunicações e outras empresas privadas continuarão a infringir a lei, uma vez que tenham incentivos econômicos para fazê-lo.

Palavras-Chave: Ilicitude lucrativa; Danos punitivos; Responsabilidade civil; Enriquecimento ilícito; Defesa do consumidor.

ABSTRACT: This article discusses the phenomenon of lucrative illegality. Because private companies take rational decisions on the violation of consumer laws and empirical observation reveals that Brazilian companies continue to violate the Consumer Defense Code (CDC), the collective actions system doesn't prevent these illegalities due to the lack of sanctions. Analyzing all 405 collective actions filed by Public Prosecutors for consumer protection at the capital by the Attorney General\&\#39;s Office of Rio de Janeiro between 1991 and 2010, sanctions imposed by judges were not sufficient to prevent collective wrongdoings. Brazilian courts should not only convict these companies for their consumer rights violations, but also impose economic sanctions and oblige them to reimburse the illegal fees that were abusively charged. Punitive damages should be optimal, deterring companies without causing excessive costs that could harm shareholders and consumers. Illegality should not be lucrative. In the current setting of under-deterrence, financial institutions, telecommunication companies, and other private businesses will continue to violate the law, once they have economic incentives to do it.

KEYWORDS: Lucrative illegality; Punitive damages; Civil liability; Unjust enrichment; Consumer protection. 


\section{INTRODUÇÃO}

Analisando o ranking nacional de reclamações de consumidores no Brasil, a tendência é encontrar um conjunto familiar de "suspeitos usuais": instituições financeiras e empresas de telecomunicações. Essas mesmas empresas são frequentemente rés em ações coletivas em todo o país. Suas transgressões coletivas são regularmente transmitidas na mídia e ainda assim essas empresas continuam violando o direito brasileiro.

O obietivo principal do presente artigo é discutir as possíveis explicacões interdisciplinares desse fenômeno, que denomino "ilicitude lucrativa". Em palavras claras, as empresas brasileiras violam o direito devido aos incentivos econômicos para fazê-lo. As acões coletivas consumeristas não são eficazes para punir os transgressores, dada a relutância dos iuízes em impor sancões econômicas efetivas. A cultura iurídica brasileira ainda vê com desconfianca o conceito estadunidense de danos punitivos e as empresas, consequentemente, têm incentivos econômicos claros para violar a lei. $\mathrm{O}$ artigo comeca com uma explicacão do conceito de "dano moral coletivo" na legislacão brasileira como ponto de partida para uma análise sócio-jurídica da dissuasão no sistema de tutela coletiva do consumo.

Primeiro, discutirei o conceito de "dano moral coletivo", um termo jurídico chave na legislação brasileira de ações coletivas. De acordo com a maioria dos comentaristas, os tribunais devem condenar as empresas a pagar "danos morais coletivos" como uma maneira de puni-los por seus erros e para evitar transgressões futuras. ${ }^{3}$ Não é surpresa que as cláusulas de "danos morais coletivos" sejam amplamente percebidas pelos acadêmicos como a base jurídica para decisões judiciais que podem impor danos punitivos a empresas. No entanto, precedentes judiciais da $1^{\underline{a}}$ Turma do Superior Tribunal de Justiça (doravante, STJ) não admitiam danos punitivos em ações coletivas. Sua justificativa dogmática implicava que as transgressões coletivas não causariam dano moral à sociedade como tal (nem às classes ou categorias de cidadãos) e, portanto, as massas de consumidores não teriam o direito de garantir "danos morais coletivos" com caráter pedagógico e punitivo. ${ }^{4}$ Além disso, a $1^{\text {a }}$ Turma também expressou inicialmente preocupação com os riscos econômicos e a imprevisibilidade dos danos punitivos. ${ }^{5}$ Por outro lado, a $2^{2}$ Turma do STJ admite danos punitivos em ações coletivas. ${ }^{6}$ Neste artigo, defenderei o argumento de que a última opinião deve prevalecer sobre a anterior, dadas as consequências negativas da recusa dos tribunais de impor indenizações de caráter punitivo em ações coletivas.

${ }^{3}$ BITTAR FILHO, Carlos Alberto. Do dano moral coletivo no atual contexto jurídico brasileiro. Revista de Direito do Consumidor. São Paulo: RT, 1994, v. 12; RAMOS, André de Carvalho. A ação civil pública e o dano moral coletivo. Revista de Direito do Consumidor. São Paulo: RT, 1998, v. 25; BESSA, Leonardo Roscoe. Dano moral coletivo. Revista de Direito do Consumidor. São Paulo: RT, 2006, v. 59.

4 REsp 971844/RS. A opinião da corte escrita pelo Ministro Teori Zavascki afirma que não há possibilidade de condenar empresas ao pagamento de dano moral coletivo nas ações coletivas.

5 REsp 971844/RS. Em seu voto, o Ministro Luiz Fux expressou preocupação com as consequências econômicas de condenar empresas ao pagamento de danos morais coletivos nas ações coletivas.

${ }^{6}$ REsp 1057274/RS.

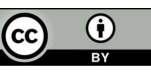


Em segundo lugar, examinarei uma amostra estatisticamente significativa de casos de ação coletiva do consumidor no Ministério Público do Estado do Rio de Janeiro (doravante MPRJ). A análise empírica revela que as empresas brasileiras possuem incentivos econômicos para infringir o direito continuadamente. Em outras palavras, o fato de uma empresa privada ser responsabilizada pela justiça brasileira não parece impedir seus agentes de violarem o Código de Defesa do Consumidor (doravante CDC) e de prejudicar um grande número de consumidores. Depois de considerar todos os casos de ações coletivas contra empresas privadas, argumento que as condenações desses réus não produziram incentivos efetivos para o cumprimento da lei. Mesmo as empresas condenadas durante este período, não receberam sanções econômicas adequadas, possuindo incentivos econômicos para cometer outras irregularidades e se tornar réus em outras ações coletivas de consumo.

Este artigo se baseia na análise empírica das 405 acões coletivas de defesa do consumidor movidas por Promotores de Iustica no Rio de Taneiro entre 1991 e 2010. Mapeando empresas que continuam violando a lei e analisando 160 sentencas, foi possível avaliar o seu impacto econômico e seu efeito de dissuasão. Além disso, nove atores legais envolvidos com as acões coletivas de tutela dos consumidores foram entrevistados e deram suas opiniões sobre os danos punitivos e o fenômeno da ilicitude lucrativa. Uma secão subsequente apresenta um estudo de caso que mostra como transgressões coletivas dos direitos do consumidor podem ser economicamente lucrativas. Em conclusão, afirmo que sancões econômicas efetivas são necessárias para prevenir o fenômeno da ilicitude lucrativa.

Um esclarecimento adicional deve ser feito ao público brasileiro: a presente pesquisa foi realizada em 2011 e publicada na línqua inglesa no IOxCSLS - Iornal do Centro de Estudos Sócio-Iurídicos da Universidade de Oxford - em 2015. O cenário se alterou desde a realizacão da pesquisa com mudanca sionificativa na iurisprudência do STI em favor do reconhecimento dos danos morais coletivos dentre nós e na experiência forense com relativo aumento de sanções econômicas impostas às empresas desde 2011 até o presente momento.

\section{A DOUTRINA BRASILEIRA DOS DANOS PUNITIVOS}

Não existe uma lei brasileira que admita claramente o instituto dos danos punitivos ou que estabeleça padrões para sua aplicação pelo Poder Judiciário. Em 2002, alguns Deputados Federais tentaram incluir no Código Civil (doravante CC) um comando normativo expresso para que os juízes imponham danos punitivos, mas este projeto legislativo nunca foi submetido ao voto do Congresso Nacional. Entretanto, o direito brasileiro desenvolveu o conceito de 'danos morais coletivos', que é a base jurídica para aplicação dos danos punitivos devido ao prejuízo causado para a sociedade como um todo como resultado de transgressões coletivas.

De acordo com o artigo 6, Inciso VI, do CDC, um dos direitos básicos dos consumidores, é "a prevenção efetiva e a compensação dos danos patrimoniais e morais, individuais, coletivos e difusos". Além disso, a Lei da Ação Civil Pública (doravante LACP) também se refere à responsabilidade pela dano moral nas ações 
coletivas, reconhecendo a existência de dano moral como resultado da poluição ambiental, violações consumeristas de massa, desordem urbana, destruição do patrimônio histórico-cultural ou práticas anticompetitivas.

Muitos acadêmicos consideram que o conceito de 'danos morais coletivos' proporciona a base jurídica para a admissão dos danos punitivos na tutela coletiva. Bittar Filho explica que o dano moral coletivo é o prejuízo injusto para a esfera moral de uma dada comunidade ou, em outras palavras, é a violação ilegal de um certo círculo de valores coletivos. ${ }^{7}$ Da mesma maneira, André Ramos enfatiza o dano moral coletivo extensivo causado pelas transgressões ilícitas coletivas, justificando compensações extra-patrimoniais para a sociedade como um todo. ${ }^{8}$ Ademais, Hugo Mazzilli, dirigindo-se a seus críticos, afirma que, por um lado, danos morais coletivos não são nada além de uma coleção de danos individuais; por outro lado, ainda aqueles que se recusem a reconhecer a soma dos danos individuais como a essência do conceito de dano moral coletivo, devem lembrar que a responsabilidade civil contemporânea prescreve uma função punitiva, adicionando um caráter extra-patrimonial para os danos morais coletivos. ${ }^{9}$ Além disso, Fredie Didier Jr e Hermes Zaneti Jr admitem a condenação ao pagamento de danos morais coletivos sempre que necessário para compensar a dor comunitária, impondo uma sanção que simultaneamente representa repreensão, compensação e que expressa uma gramática coexistencial da sociedade contemporânea, com um caráter pedagógico principal. ${ }^{10}$ Ademais, Roscoe Bessa entende que o conceito de "danos morais coletivos" proporciona uma base jurídica para o reconhecimento dos danos punitivos no sistema de tutela coletiva de direitos brasileiro. Para ele, a tutela coletiva nos força a construir soluções que usam simultaneamente conceitos de responsabilidade civil e também a perspectiva específica do direito penal. ${ }^{11}$

Teori Zavascki, então Professor de Direito na Universidade de Brasília, escreveu uma crítica eloquente ao conceito de 'dano moral coletivo'. Primeiro, ele afirmou que "compensação e punição são imposições jurídicas distinguíveis e, no caso dos danos, a compensação é devida, conforme as normas que regem o sistema de responsabilidade civil. Entretanto, mesmo no evento de séria ilegalidade e ofensa, a imposição de qualquer punição não estabelecida anteriormente pela lei é puramente arbitrária, conforme o nosso sistema normativo, um ato arbitrário que não é atenuado - ao contrário, se torna ainda mais evidente - quando as punições estão disfarçadas sob o rótulo de condenação devida como danos morais. ${ }^{12}$ Ademais, Teori Zavascki

7 BITTAR FILHO, Carlos Alberto. Do Dano Moral Coletivo no Atual Contexto Jurídico Brasileiro. Revista de Direito do Consumidor. São Paulo: RT, 1994, v. 12, p. 55.

8 RAMOS, André de Carvalho. A ação civil pública e o dano moral coletivo. Revista de Direito do Consumidor. São Paulo: RT, 1998, v. 25, p. 83.

${ }_{9}$ MAZZILLI, Hugo Nigro. A defesa dos interesses difusos em juízo. São Paulo: Saraiva, 21aㅡ edição, 2008, p. 146.

${ }^{10}$ DIDIER JR, Freddie; ZANETI JR, Hermes. Curso de Direito Processual Civil: processo coletivo. São Paulo: JusPodivm, $4^{\underline{a}}$ ed., 2009, p. 295-296.

11 BESSA, Leonardo Roscoe. Dano Moral Coletivo. Revista de Direito do Consumidor. São Paulo: RT, 2006, v. 59.

12 ZAVASCKI, Teori Albino. Processo coletivo: tutela de direitos coletivos e tutela coletiva de direitos. São Paulo: RT, 4ª ed., 2009, p. 40.

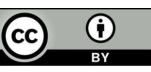


argumentou que "a vítima dos danos morais é, necessariamente, uma pessoa. O dano moral abrange, necessariamente, sofrimento, dor e ofensa psicológica. ${ }^{13}$ Em sua conclusão, ele argumentou que o direito não pode transformar a essência dos fenômenos, nem suas consequências jurídicas e, assim, não se deve interpretar a LACP como tendo criado um conceito exótico de 'danos morais coletivos'. ${ }^{14}$

O Professor Teori Zavascki também era Ministro do STJ por ocasião da elaboração da pesquisa original. ${ }^{15}$ Coerente com seus trabalhos acadêmicos, o Ministro Teori Zavascki tinha expressado a mesma opinião em seus julgamentos na $1^{\text {a }}$ turma do STJ. ${ }^{16}$ Como relator, o Ministro Teori Zavascki afirmou que os danos morais exigem dor individual e sofrimento psicológico e que os danos morais coletivos não podem ser impostos como resultado do dano causado à sociedade como tal. De acordo com o Ministro Teori Zavascki, a proteção ambiental não exige uma condenação para responsabilizar a parte pelo pagamento dos danos morais coletivos, já que a ordem judicial para a recomposição do ecossistema degradado seria suficiente para a proteção da natureza. ${ }^{17}$

${ }^{13}$ Ibid, p. 41.

14 Ibid, p. 42-43.

${ }^{15}$ O Ministro Teori Zavascki deixou o STJ e se tornou Ministro no Supremo Tribunal Federal (STF) em 29 de novembro de 2012.

${ }_{16} \mathrm{O}$ caso pioneiro em questão foi Ministério Público de Minas Gerais vs Município de Uberlância e Empreendimentos Imobiliários Canaã Ltda (REsp 598281, 01/06/2006). A promotoria de proteção do meio ambiente ajuizou uma ação coletiva em face do município e de uma empresa por um empreendimento ilegal que causou degradação ambiental. Os réus foram condenados e orbigados a demolir todas as construções, recompor as áreas degradadas e restaurar a natureza local. Além disso, o Juízo de primeiro grau condenou os réus ao pagamento de $\mathrm{R} \$ 50,000$ a título de danos morais coletivos causados pela conduta ilegal e descuidada. No julgamento da apelação, o juízo de segundo grau reverteu essa condenação ao dano moral coletivo, afirmando que os danos morais coletivos são cabíveis apenas se existir sofrimento individual. $\mathrm{O}$ acórdão concluiu que não existe um conceito de 'dano moral coletivo' no direito brasileiro. Logo, o MPMG interpôs o Recurso Especial ao STJ e o caso foi distribuído para a 1a Turma. O Ministro Luiz Fux (acompanhado pelo Ministro Delgado) escreveu a opinião minoritária, em que ressaltava a ideia de que o Artigo 6, VI, do CDC e o Artigo 1o da LACP admitiam a condenação judicial dos réus de ações coletivas ao pagamento de danos morais coletivos.. Citando inúmeras opiniões acadêmicas, o Ministro Fux sustentou que a principal preocupação dos juízes, nesses casos, é a prevenção dos danos ambientais, devido ao status constitucional da proteção ambiental, o que impediria a interpretação restritiva a essa proteção. Concluindo sua opinião, o Ministro Fux mencionou que os danos patrimoniais e extra-patrimoniais devem coexistir, interpretação que favorece o meio ambiente equilibrado e saudável garantido pela constituição brasileira.

${ }_{17}$ O Ministro Francisco Falcão aderiu ao voto. A Ministra Denise Arruda concordou com o julgamento, mas fez a ressalva que admitia a possibilidade de condenação por danos morais coletivos, apesar de não ser aplicável ao caso concreto. Em sua opinião, ela pontuou que existem situações em que certamente os danos extra-patrimoniais irão ser compensados por medidas objetivas para restauração física e por uma compensação monetária devido ao prejuízo difuso e coletivo. Entretanto, a Ministra Denise Arruda não encontrava evidência de danos extra-patrimoniais para a comunidade no caso. Apesar de ser uma decisão dividida, o caso foi seguido como se fosse um precedente pela $1^{\mathrm{a}}$ Turma do STJ. No julgamento seguinte pela corte, Ministério Público do Rio Grande do Sul e Município de Uruguaiana vs. Eletrojan Iluminação e Electricidade Ltda (REsp 821.891-RS, 12/05/2008), o Ministro Fux escreveu a opinião unânime da Turma, seguindo o precedente estabelecido no julgamento prévio e afirmou que os danos morais coletivos são inadmissíveis. A $1^{\text {a }}$ Turma teve outra oportunidade de 
Em contraste com esses precedentes da $1^{\text {a }}$ Turma, a $2^{\text {a }}$ Turma do STJ não apenas admitia, mas também elogiava o conceito de dano moral coletivo como sendo um instrumento relevante para prevenção das transgressões coletivas. Em uma primeira decisão, ${ }^{18}$ a Ministra Eliana Calmon discordou veementemente da linha decisória da $1^{\text {a }}$ Turma: eu não posso aceitar a conclusão da $1^{\text {a }}$ Turma, já que evidência de dor, sofrimento ou danos psicológicos são inessenciais para caracterizar dano extrapatrimonial. Em uma opinião contundente de uma votação unânime, a Ministra Eliana Calmon acrescentou que violações em massa a direitos não podem restar irreparadas, já que iria acarretar em falhas no direito para a prevenção e compensação de conflitos sociais. Em outro caso subsequente, ${ }^{19}$ a $2^{\text {a }}$ Turma do STJ de forma unânime também manteve uma condenação ao pagamento de dano moral coletivo de cento e vinte mil reais.

Os precedentes conflitantes do STJ evidenciam a importância da pesquisa acadêmica. São os danos extra-patrimoniais na tutela coletiva necessários para a efetiva prevenção das violações em massa de direitos dos consumidores? A análise empírica das ações coletivas de proteção do consumidor demonstram que a ausência de sanções econômicas efetivas criam um cenário de aplicação imperfeita do direito e induzem a ilicitude lucrativa. A próxima seção irá avançar o argumento a partir de dados quantitativos extraídos da experiência forense brasileira.

\section{O MAPEAMENTO DAS AÇÕES COLETIVAS DE PROTEÇÃO DO CONSUMIDOR}

O CDC foi promulgado em 1990 e entrou em vigência em março de $1991 .{ }^{20}$ O Título III do Código regula as ações coletivas consumeristas, sendo que as regras variam consideravelmente do modelo estadunidense de tutela coletiva. Primeiro, indivíduos não podem ser autores nas ações coletivas consumeristas brasileiras. Por uma decisão de política pública, o papel de autor nas ações coletivas é reservado a promotores de justiça, defensores públicos, associações privadas, sindicatos e por entes estatais. ${ }^{21}$ Segundo, não há um procedimento para a certificação da classe ou análise de representatividade adequada no Brasil, já que esses autores são legitimados pelo CDC

reafirmar esses precedentes em dois outros casos. In Ministério Público Federal vs. Brasil Telecom S/A e Agência Nacional de Telecomunicações (ANATEL) (REsp 971.844/RS, 12/02/2010), o Ministro Zavascki escreveu a opinião unânime da turma, seguindo as decisões anteriores. O Ministro Fux aderiu e escreveu uma opinião simplesmente para expressar sua preocupação com os riscos econômicos, incerteza jurídica e a necessidade de garantir o equilíbrio econômico dos contratos no mercado de telecomunicações para proteção dos investimentos crescentes. Em um caso análogo, Ministério Público Federal vs. Brasil Telecom S/A (REsp 1109905, 03/08/2010), o Ministro Hamilton Carvalhido escreveu a opinião unânime da turma e seguiu a mesma linha.

18 Ministério Público do Rio Grande do Sul vs. Empresa Bento Gonçalves de Transportes Ltda. (REsp 1057274/RS, 01/12/2009).

${ }^{19}$ Ministério Público Federal e Agência Nacional de Telecomunicações (ANATEL) vs. Brasil Telecom S/A (REsp 1150530/SC, 18/02/2010).

${ }^{20}$ Lei Federal no 8.078/90 (CDC).

${ }^{21}$ Artigo 82 do CDC.

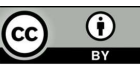


para atuar em nome da massa de consumidores. ${ }^{22}$ Terceiro, autores estão isentos de custas legais, incluindo as taxas judiciárias e os honorários advocatícios. A seu turno, a litigiosidade frívola e de má fé devem resultar no pagamento de multa correspondente a dez vezes o valor das custas legais (além dos honorários advocatícios e sem prejuízo da responsabilização por perdas e danos). ${ }^{23}$ Quarto, regras de evidência não incluem o procedimento de descoberta ('discovery'), mas podem implicar na reversão do ônus da prova em favor dos autores. Ademais, o Ministério Público pode iniciar seus inquéritos civis para coletar documentos, depoimentos de testemunhas e produzir a prova necessária para respaldar suas ações coletivas. ${ }^{24}$

\section{Proteção do consumidor: papel dos Promotores de Justiça}

Um número reduzido de ações coletivas consumeristas foi ajuizado imediatamente após a promulgação do CDC. Por exemplo, no Município do Rio de Janeiro, promotores de justiça ajuizaram apenas 24 ações coletivas consumeristas em face de empresas privadas entre 1991 e 2001.

Figura 1 - Período Preliminar de Ações Coletivas Consumeristas (1991-2001).

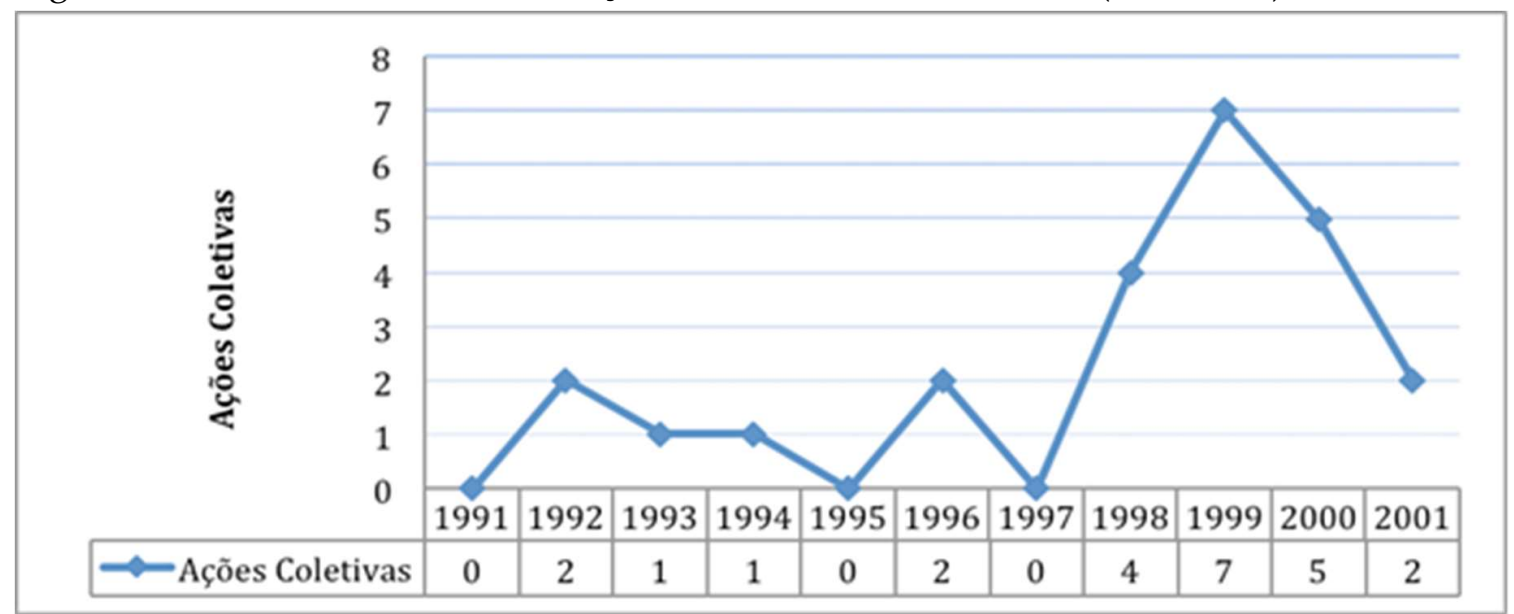

Fonte: Acervo MPRJ

Há muitas razões potenciais para o número limitado de ações coletivas durante esta primeira década: falta de doutrina consolidada sobre a nova legislação; falta de estrutura para conduzir investigações e coletar evidências de transgressões coletivas; falta de independência dos promotores de justiça, uma vez que eram designados pelo Procurador Geral de Justiça e agiam por delegação; falta de especialização para

${ }^{22}$ Veja GIDI, Antonio. A class action como instrumento de tutela coletiva de direitos: as ações coletivas em uma perspectiva comparada. São Paulo: RT, 2007.

${ }^{23}$ Artigo 87 do CDC; Artigo 17 da Lei Federal no 7.347/85.

${ }^{24}$ Artigo 6, VII, do CDC; Artigo 8 da Lei Federal nº 7.347/85. 
conduzir investigações civis, já que a formação profissional dos promotores de justiça tinha sido essencialmente na aplicação do direito penal.

Figura 2 - Período Intermediário de Ações Coletivas Consumeristas (2002-2006)

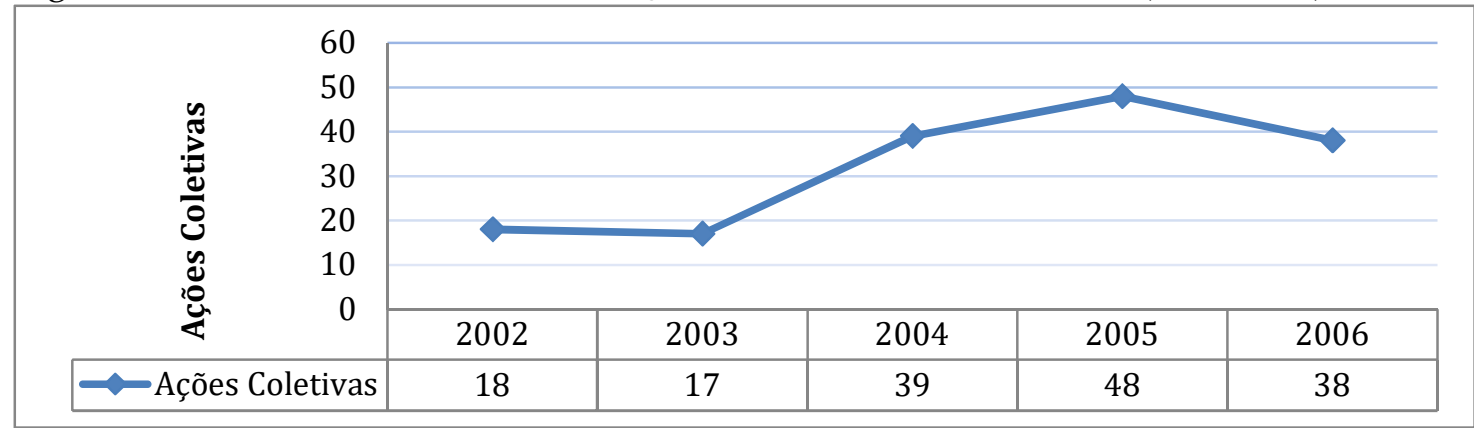

Fonte: Acervo MPRJ

O MPRJ reestruturou as Promotorias de Justiça de tutela coletiva do consumidor da capital em 2001, designando quatro promotores independentes, cujas investigações, acordos e ações contenciosas não estariam mais sob o controle direto do Procurador Geral de Justiça. A independência aumentou a produtividade, na medida em que não era mais necessário buscar aprovação hierárquica ou se preocupar com as consequências políticas de processar empresas privadas. Além disso, a estrutura necessária para realizar inquéritos civis foi finalmente estabelecida e proporcionou que fossem coletadas evidências mais detalhadas para respaldar as ações coletivas. A designação de quatro promotores independentes com estabilidade funcional e caráter de permanência também trouxe conhecimento técnico, já que a crescente experiência e credibilidade gradualmente melhoraram a qualidade de seu trabalho e a quantidade de ações coletivas ajuizadas. Como consequência, os promotores de justiça de defesa do consumidor iniciaram 160 ações coletivas consumeristas contra empresas privadas nos cinco anos subsequentes.

Figura 3 - Período Recente de Ações Coletivas Consumeristas (2007-2010)

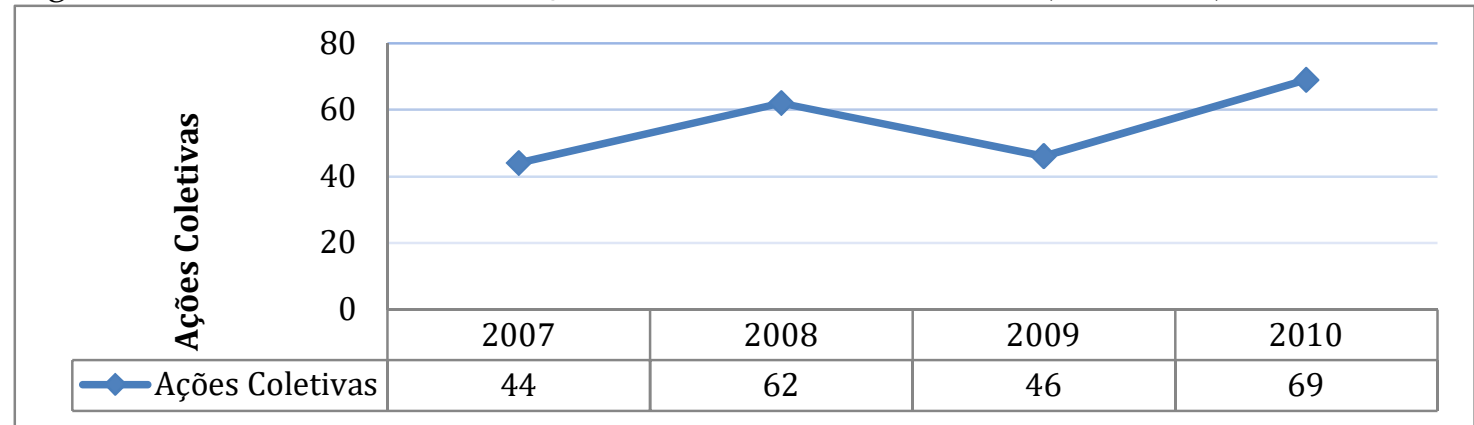

Fonte: Acervo MPRJ 
Esses casos fornecem uma excelente amostra para avaliar a efetividade do sistema brasileiro de tutela coletiva de direitos. A análise empírica dessas ações coletivas de defesa do consumidor mostra que essas empresas privadas são frequentemente condenadas, mas não recebem sanções econômicas apropriadas para suas transgressões coletivas. Além disso, o tempo excessivo de duração dos julgamentos prejudica a efetividade de suas punições. Consequentemente, as empresas privadas não têm incentivos econômicos para cumprir a lei. Como resultado, as empresas podem tornar a delinquir e novas ações coletivas podem vir a ser ajuizadas. Entre 2007 e 2010, os promotores de justiça defesa do consumidor ajuizaram 221 ações coletivas contra empresas privadas.

Figura 4 - Total de Ações Coletivas Consumeristas em duas décadas (1991-2010)

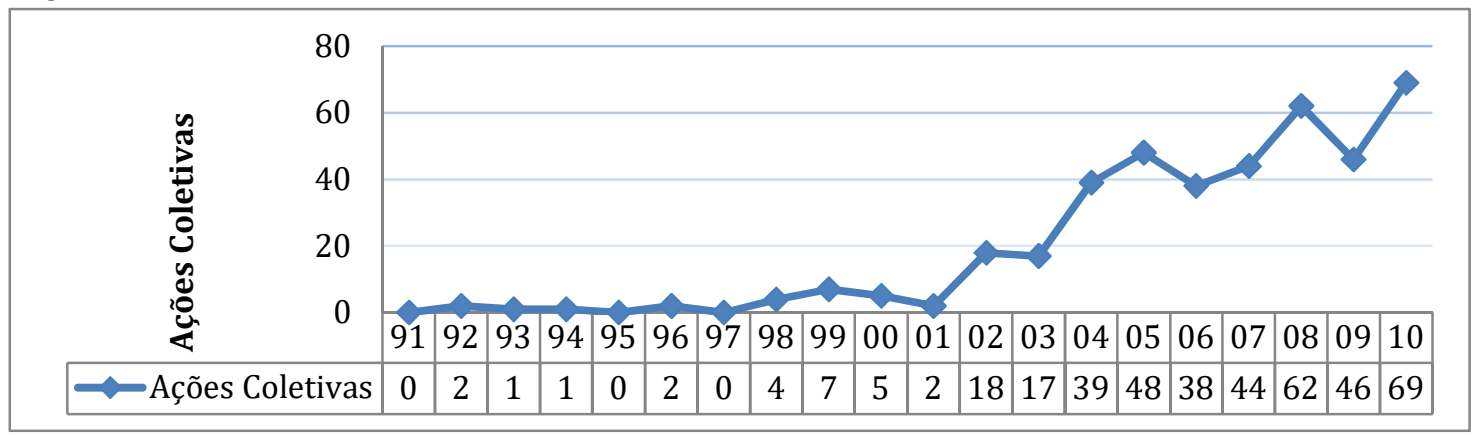

Fonte: Acervo MPRJ

Antes de processar as empresas privadas, os promotores de justiça normalmente propõem acordos, que envolvem o compromisso de parar de infringir a lei e pagar indenizações aos consumidores prejudicados. As condições de tais pagamentos são negociáveis e podem ser parceladas de acordo com a capacidade financeira da empresa. No entanto, a maioria das empresas se recusa a negociar e prefere litigar. Assumindo que as empresas geralmente têm aversão ao risco e tomam decisões com base em análises racionais, fica claro que o sistema carece de sanções econômicas para impedi-las de continuar infringindo a lei.

A próxima seção identificará quem são os réus nesses 405 casos, ao longo dos primeiros vinte anos de existência das promotorias de justiça de tutela coletiva do consumidor no MPRJ.

\section{Suspeitos usuais: identificando os transgressores}

Mapeando o acervo de espelhos (cópias completas dos processos judiciais existentes para fins de acompanhamento no MPRJ) de ações coletivas de proteção ao consumidor, foram observados três períodos de tempo diferentes: período inicial (1991-2001); período intermediário (2002-2006); e período recente (2007-2010).

No período preliminar, 24 ações coletivas foram ajuizadas. Instituições financeiras e empresas de telecomunicações já estavam entre os réus habituais. Algumas dessas 
ações coletivas pretenderam limitar as taxas de juros e não obtiveram sucesso, devido à relutância do judiciário em intervir em questões econômicas. Todas as três ações coletivas contra empresas de telecomunicações focaram em práticas de propaganda abusiva para vender linhas telefônicas.

Tabela 1 - Período Preliminar (1991-2001). Ações Coletivas por categoria de réu e percentagem

\begin{tabular}{lcc}
\hline \multicolumn{1}{c}{ Réus nas A çöes Coletivas } & Casos (1991-2001) & Percentagem (\%) \\
\hline Instituições Financeiras & 7 & 29.1 \\
Construção e Im obiliária & 4 & 16.7 \\
Empresas de Telecomunicações & 3 & 12.5 \\
Seguradoras de Saúde & 3 & 12.5 \\
Automóveis & 2 & 8.3 \\
Seguradoras em geral & 1 & 4.2 \\
Outras empresas & 4 & 16.7 \\
\hline Total & $\mathbf{2 4}$ & $\mathbf{1 0 0}$
\end{tabular}

Fonte: Acrvo do MPRJ.

Nessa década inicial, houve também um número significativo de ações coletivas contra empresas imobiliárias e habitacionais. Em um desses casos, os apartamentos foram vendidos, mas não entregues a todos os futuros proprietários. Dois outros casos envolveram cobranças ilegais devido a perdas de inflação. Finalmente, um quarto caso envolveu o colapso de um prédio que teve que ser demolido devido à falha do projeto e ao uso de materiais de construção de baixa qualidade. Este processo coletivo ficou conhecido como o caso do Edifício Palace c estabeleceu um precedente relevante, uma vez que se decidiu que os promotores de justiça não deveriam entrar com ações coletivas em nome dos proprietários de apartamentos e que esses proprietários precisavam ir aos tribunais para defender seus próprios direitos. Logo, a percentagem de ações coletivas contra empresas imobiliárias e de construção diminuiu significativamente nos anos seguintes, limitando-se apenas a questões relativas a problemas contratuais, mas não a falhas de construção.

Não houve ações coletivas contra empresas de transporte ou de energia nesse período inicial. Esses tipos de empresas se tornaram gradativamente rés habituais durante o período intermediário e rés em diversas ações coletivas no período recente. Há duas explicações diferentes para a completa inexistência de ações ajuizadas contra empresas de energia e transporte durante esse período inicial. Primeiro, a investigação para coletar evidências de falhas na prestação de serviços requer uma estrutura muito sofisticada e os promotores não a possuíam durante a década de 1990. Em segundo lugar, durante essa década inicial, a companhia de eletricidade, as barcas, o metrô e o sistema de trens urbanos eram públicos. Eles foram privatizados no final daquela década e as reclamações dos consumidores por melhores serviços aumentariam significativamente nos anos seguintes.

No período intermediário, o acervo mostrou uma variedade muito maior de casos, incluindo diferentes setores de negócios e atividades de lazer. A variedade de casos variou de acidentes em parques de diversões a negociações abusivas de jazigos em 
cemitérios. A promulgação do Estatuto do Torcedor (Lei $\mathrm{n}^{\mathrm{o}}$ 10.671/03) reconheceu status de consumidores dos torcedores e a base jurídica para o que clubes e federações fossem processados judicialmente. ${ }^{25}$ Além disso, a competição crescente entre agências de turismo resultou em uma série de ações coletivas devido a propaganda enganosa, comportamento fraudulento e acusações de transgressões coletivas. Grupos educacionais também foram responsabilizados por cobrar taxas ilegais. Além disso, empresas de transporte e energia finalmente apareceram como réus em ações coletivas de proteção ao consumidor nesses anos intermediários. Não obstante, os réus habituais continuaram a violar o CDC e a maioria das ações coletivas foi movida contra instituições financeiras, empresas de telecomunicações, seguradoras de saúde e empresas imobiliárias. Durante esse período intermediário, esses quatro tipos de empresas foram réus em $61,9 \%$ dos casos, um percentual não muito distante do período inicial: $70,8 \%$.

Tabela 2 - Período Intermediário (2002-2006). Ações coletivas por categoria de réu e percentagem

\begin{tabular}{lcc}
\hline \multicolumn{1}{c}{ Réus nas Açöes Coletivas } & Casos(2002-2006) & Percentagem (\%) \\
\hline Institui ções Financeiras & 36 & 22.5 \\
Empresas de Telecomunicações & 31 & 19.4 \\
Seguradoras de Saúde & 21 & 13.1 \\
Construt ora e Imobiliária & 11 & 6.9 \\
Empresa de Energia & 09 & 5.6 \\
Agências de Turismo & 06 & 3.8 \\
Lazer (parques, música, etc) & 05 & 3.1 \\
Transporte de passageiros & 04 & 2.5 \\
Clubes esportivos e competições & 04 & 2.5 \\
Automóveis & 03 & 1.9 \\
Lojas de Departmento & 03 & 1.9 \\
Grupos Educacionais & 03 & 1.9 \\
Seguradoras em geral & 02 & 1.2 \\
Shopping centers & 01 & 0.6 \\
Outras empresas & 21 & 13.1 \\
\hline \multicolumn{1}{c}{ Total } & $\mathbf{1 6 0}$ & $\mathbf{1 0 0}$ \\
\hline
\end{tabular}

Fonte: Aœrvo do MPRJ.

${ }^{25}$ Sobre o Estatuto do Torcedor, veja FORTES, Pedro R. B. The Law related to Brazilian Sports Fans: An Introduction for a British Audience. Entertainment and Sports Law Journal, v. 11, n. 2, 2013; FORTES, Pedro R. B. War and peace among organized support groups: the challenge of ensuring safety in football stadiums. Caderno FGV Projetos, v. 22, p. 86, 2013; FORTES, Pedro R. B. We The Fans: Should International Football Have Its Own Constitution?, Southwestern Journal of International Law, v. 21, 2014, p. 63; FORTES, Pedro R. B. Das Brasilianische Sport-Fan Gesetz: eine Einführung für das deutsche Publikum, Mitteilungen der Deutsch-Brasilianischen Juristenvereinigung, v. 1, p. 68, 2014; FORTES, Pedro R. B. A responsabilidade coletiva de torcidas organizadas. Revista do Ministério Público do Estado do Rio de Janeiro, v. 48, p. 211, 2013. 
No período recente, instituições financeiras e empresas de telecomunicações continuaram a ser processadas por promotores. Em termos absolutos, houve 36 ações coletivas contra instituições financeiras em cada um dos períodos. Em relação às empresas de telecomunicações, o número de ações coletivas de proteção ao consumidor aumentou de 31 (2002-2006) para 36 (2007-2010). Essas empresas mantiveram seu status de "suspeitos usuais" e são empresas privadas que continuam violando a lei, independentemente do fato de que elas são repetidamente acusadas em ações coletivas de transgressões coletivas dos direitos do consumidor.

Também é importante notar o crescimento substancial do número de casos envolvendo ônibus, trens, metrô, táxis e o sistema de barcas: 1275\%. Embora não tenham sido coletados dados específicos sobre as multas impostas a essas empresas pela Agência Estadual de Transportes (Agetransp) e pela Autoridade Municipal e Estadual de Transportes (SMTr e DETRO), uma possível explicação pode vir da falta de controle efetivo e sanções econômicas por parte das agências reguladoras e do poder executivo. Durante anos, os promotores requisitaram informações dessas agências e não receberam os relatórios solicitados. Em 2010, no entanto, houve uma transformação positiva na Autoridade Municipal, cuja Secretaria se concentrou mais na fiscalização e no controle de qualidade do serviço. Desde então, relatórios detalhados e imediatos de fiscalização passaram a ser enviados regularmente para as Promotorias de Justiça de Tutela Coletiva de Defesa do Consumidor da Capital. Nos primeiros três meses de 2011, nenhuma ação coletiva foi movida contra uma empresa de transporte.

Tabela 3 - Período recente (2007-2010). Ações coletivas por categoria de réus e percentagem

\begin{tabular}{lcc}
\hline \multicolumn{1}{c}{ Réus nas Ações Coletivas } & Casos (2007-2010) & Percentagem (\%) \\
\hline Transporte de passag eiros & 51 & 23.0 \\
Institui ções Financeiras & 36 & 16.3 \\
Empresas de Telecomunicações & 36 & 16.3 \\
Clubes esportivos e competições & 11 & 5.0 \\
Empresas de energia & 10 & 4.5 \\
Lojas de Departmento & 10 & 4.5 \\
Seguradoras de Saúde & 10 & 4.5 \\
Shopping centers & 10 & 4.5 \\
Grupos Educacionais & 06 & 2.8 \\
Construtora e Imobiliária & 05 & 2.3 \\
Lazer (circo, música, etc) & 04 & 1.8 \\
Agência de Turismo & 03 & 1.4 \\
Seguradora em Geral & 03 & 1.4 \\
Automóvel & 02 & 0.9 \\
Outras empresas & 24 & 10.8 \\
\hline \multicolumn{1}{c}{ Total } & $\mathbf{2 2 1}$ & 100
\end{tabular}


As agências requladoras e as autoridades executivas também desempenham um papel essencial no caso da protecão do consumidor. Se elas regulam seus mercados de acordo com o CDC, as empresas privadas terão um coniunto claro de regras a serem cumpridas. No entanto, definir diretrizes, normas e deveres não é suficiente. Sem sancionar adequadamente as irregularidades, essas agências e autoridades testemunharão o fenômeno da lucrativa ilegalidade: as empresas violarão constantemente a lei se tiverem incentivos econômicos para fazê-lo.

No presente artigo, no entanto, não procuro descrever o fenômeno da ilegalidade lucrativa observando as agências reguladoras. O foco está na inefetividade do sistema brasileiro de ações coletivas. A próxima seção analisará todas as 160 ações coletivas do período intermediário e seus resultados.

\section{Culpado ou inocente? - analisando as sentenças}

A pesquisa quantitativa indica duas razões principais para a inefetividade das acões coletivas dos consumidores brasileiros. Em primeiro lugar, a falta de sancões econômicas para os infratores fornece incentivos econômicos para as empresas infringirem a lei. Em segundo lugar, a lentidão do sistema judiciário brasileiro afeta sua capacidade de evitar novas transgressões coletivas.

Figura 5 - Resultados das ações coletivas consumeristas do período intermediário (2002-2006)

\begin{tabular}{|c|c|c|c|c|}
\hline Resultados dos Julgamentos & fondenaçõe & Absolvições & Acordos & Aguardando \\
\hline Ações Coletivas (2002-2006) & 21 & 29 & 34 & 72 \\
\hline Percentagem das Ações Coletivas Conforme Tipo de \\
Resultado \\
(2002-2006) \\
Aguardando \\
Julgamento \\
$46 \%$
\end{tabular}

Fonte: acervo do MPRJ (checado em abril de 2011).

Analisando a amostra de 160 ações coletivas, não havia em abril de 2011 um único caso de condenação definitiva obrigando uma empresa a pagar indenização por dano moral coletivo de caráter punitivo. As empresas foram condenadas em 21 casos, mas 
sanções econômicas efetivas não foram impostas em nenhum desses julgamentos. Elas foram absolvidas em 29 julgamentos. Os promotores e advogados de empresas privadas fecharam acordos em 34 ações coletivas e a negociação quase sempre envolvia o compromisso do réu com o cumprimento do CDC sem a imposição de qualquer sanção econômica devido a uma violação anterior da legislação. Excepcionalmente, uma vez, bancos privados concordaram em pagar uma multa de dez milhões de reais como parte de um acordo com o Ministério Público. 72 ações coletivas ainda estavam aguardando sentenças ou julgamentos de apelação finais em abril de 2011. Em apenas três casos, empresas privadas foram condenadas a pagar indenizações por dano moral coletivo de caráter punitivo. Devido a propaganda ilegal, uma empresa foi condenada a pagar $\mathrm{R} \$ 500.000,00$. Pela mesma razão, uma empresa de telecomunicações pode ser obrigada a pagar $\mathrm{R} \$ 70.000,00$. Finalmente, devido ao comércio ilícito de combustível, três diferentes empresas de postos de gasolina foram condenadas a pagar $\mathrm{R} \$ 70.000,00$. Todas as três condenações foram confirmadas pelo tribunal e aguardam julgamento do recurso especial no STJ.

Além da falta de indenizações de caráter punitivo, o complexo sistema brasileiro de tutela coletiva também não obriga, na prática, as empresas privadas a compensar os consumidores por suas perdas econômicas. Ao contrário do sistema americano, o Brasil não possui um procedimento de descoberta para coletar evidências sob regras de divulgação completa. Portanto, as empresas não são obrigadas a fornecer informações detalhadas sobre o montante exato de todas as tarifas abusivas cobradas de cada consumidor ou revelar o valor total do lucro resultante da violação da lei. Além disso, o sistema brasileiro não possui um procedimento efetivo de notificação do consumidor lesado. De acordo com o CDC, os consumidores devem ser avisados sobre a existência de uma ação coletiva, sendo suficiente a publicação de um edital no diário oficial do tribunal. Como consequência, a maioria dos consumidores desconhece esses casos e não acompanha os julgamentos. ${ }^{26}$ Finalmente, o sistema brasileiro de tutela coletiva exige que os consumidores sejam proativos para receber remuneração. Uma vez que uma decisão judicial definitiva condenar uma empresa privada a indenizar as vítimas por suas perdas econômicas, o sistema brasileiro espera que cada consumidor contrate um advogado e participe individualmente do processo coletivo para exigir sua parcela de remuneração. Considerando que a maioria desses casos está relacionada à cobrança ilegal de um valor econômico módico, a maioria das vítimas não se dá ao trabalho de reivindicar suas indenizações individuais nos tribunais. Dada a falta de informação sobre o montante total de perdas econômicas, os promotores de justiça podem não ser capazes de forçar essas empresas a fazer um depósito no Fundo de Defesa do Consumidor, como uma alternativa para a compensação individual dos consumidores.

Examinando todos os 21 casos de julgamentos de ação coletiva com condenações definitivas em abril de 2011, não havia nenhum caso em que os consumidores individuais foram devidamente compensados. De fato, nove sentenças declararam que houve violação da lei e obrigaram as empresas a cumprir o CDC, mas não condenaram esses réus a pagar indenização compensatória. Outras 12 condenações obrigaram as

${ }^{26}$ Artigo 92 do CDC. 
empresas a compensar totalmente as perdas das vítimas, mas no final essas decisões não impuseram sanções econômicas aos infratores, uma vez que os consumidores individuais não reivindicaram sua parte de danos e os promotores ainda não tinham aplicado a regra legal de recuperação fluida desses valores na ausência de pagamento individual de indenizações. ${ }^{27}$

Vale a pena notar que essas condenações não são meramente simbólicas, já que os juízes adotam as medidas necessárias para impor o cumprimento de suas próprias decisões após os julgamentos de uma ação coletiva. Portanto, uma vez que uma ordem judicial de cumprimento da lei seja definitiva, os juízes irão impor uma multa significativa às empresas desobedientes. A maioria das instituições financeiras e empresas de telecomunicações não questionam essas decisões judiciais e tendem a não cometer a mesma irregularidade repetidamente. Por outro lado, como esses réus não experimentam nenhum tipo de punição econômica pela sua delinquência anterior, eles também não têm incentivos econômicos efetivos para se abster de cobrar outras tarifas ilegais, violar outras cláusulas do CDC ou adotar qualquer outra prática abusiva. Dados empíricos revelam que essas empresas enfrentam um risco mínimo de sofrer qualquer tipo de punição econômica, desde que não questionem uma ordem proibitiva de um juiz.

Este contexto de sub-dissuasão ou dissuasão imperfeita ("under-deterrence", conforme a terminologia técnica estadunidense) fornece uma explicação clara para todos os acordos negociados sem a imposição de compensação econômica. Até 2011, os promotores não esperavam impor danos punitivos por meio de ações coletivas consumeristas e estavam cientes de que seria improvável que as vítimas individuais reivindicassem indenização compensatória nesses casos. Portanto, esses promotores tinham incentivos claros para negociar acordos em que empresas privadas se comprometiam com o cumprimento imediato da lei. Como os litígios coletivos no Brasil costumavam durar muitos anos, as empresas eram avessas ao risco e fechavam acordos quando previam a possibilidade de um risco concreto de punição econômica ainda que no futuro remoto. Até abril de 2011 havia apenas um caso excepcional em que uma instituição financeira decidiu pagar dez milhões de reais como parte de um acordo para encerramento de uma ação coletiva, provavelmente evitando o risco de ser condenada com uma punição econômica maior no julgamento posteriormente.

Finalmente, por ocasião da análise empírica, em abril de 2011, havia várias ações coletivas aguardando uma decisão final. No acervo de ações coletivas do período intermediário, 72 ações coletivas ainda aguardavam sentenças ou julgamentos finais de recurso. Em 26 casos, já havia sentença do juiz da Vara Empresarial da Comarca da Capital e julgamento da apelação foi julgada pelo Tribunal de Justiça do Estado do Rio de Janeiro (doravante TJRJ). Esses casos aguardavam então uma decisão final do Supremo Tribunal Federal (doravante STF) ou do STJ. 29 ações coletivas tinham sido julgadas pelo Juiz da Vara Empresarial e estavam aguardando o julgamento de uma apelação. Ainda havia 17 processos coletivos aguardando uma sentença de primeira instância pelos juízes das Varas Empresariais.

${ }^{27}$ Artigo 100 do CDC. 
A lentidão é extremamente preiudicial para os consumidores por vários motivos. Em primeiro lugar, eles são privados de recursos monetários retidos ilegalmente por empresas privadas. Em sequndo lugar, na ausência de uma liminar, as empresas continuarão a repetir a prática contestada até uma decisão definitiva e privarão os consumidores de seus direitos. Terceiro, a duracão prolongada do tempo desmobilizará os consumidores e as vítimas individuais provavelmente não serão totalmente compensadas por empresas privadas.

\section{O FENÔMENO DA ILICITUDE LUCRATIVA}

Além da análise quantitativa, nove atores iurídicos foram entrevistados: três promotores de iustica; dois iuízes; um defensor público; um advogado da Comissão de Defesa do Consumidor da Assembleia Legislativa do Estado do Rio de Taneiro (doravante ALERT); dois advogados de empresas privadas (iurídico de uma instituicão financeira e iurídico de uma empresa de telecomunicacões). Todos esses atores iurídicos estavam trabalhando em $2011 \mathrm{com}$ as acões coletivas consumeristas no Rio de Taneiro e suas opiniões vinham de anos de experiência profissional na área. Entrevistas foram conduzidas com o obietivo de obter suas opiniões sobre danos punitivos, sanções econômicas e o fenômeno da ilegalidade lucrativa.

\section{Falta de danos punitivos}

Os demandantes criticaram, por exemplo, a falta de indenizações por danos morais coletivos de caráter punitivo nas ações coletivas no Rio de Janeiro. Segundo o defensor público, o advogado da Comissão e os promotores de justiça, as empresas privadas quase nunca tinham sido condenadas a pagar indenizações por dano moral coletivo de caráter punitivo. De acordo com esses profissionais, os tribunais são conservadores: os juízes foram forjados em uma cultura jurídica de responsabilidade civil clássica e, portanto, relutariam em punir as empresas por seus erros. Suas sentenças eram muitas vezes limitadas a proibir um ato ilegal e a compensar danos patrimoniais. Dois entrevistados referiram-se ao fato de que a tutela coletiva de direitos é relativamente nova no Brasil e que a doutrina ainda não estaria consolidada, de modo que tem esperança de que a cultura jurídica possibilitará a aplicação efetiva dos danos punitivos no futuro. Dois entrevistados referiram-se às origens americanas dos danos punitivos e ao preconceito que alguns casos emblemáticos alimentaram na comunidade jurídica brasileira. O defensor público também lembrou o fato de que não existe lei que admita expressamente a aplicação dos danos punitivos no Brasil. Um dos juízes também se referiu à inexistência de um mandado legal expresso como sendo uma explicação para a falta de uma cultura de punição econômica.

Indagado especificamente sobre se o conceito de "danos morais coletivos" poderia permitir a condenação de empresas a pagar indenizações por danos punitivos, todos os entrevistados concordaram, exceto o jurídico do banco. Ele argumentou que os danos morais são pessoais e não afetam a sociedade como tal. $O$ jurídico de telecomunicações admitiu a possibilidade de condenação a título de danos punitivos, mas também mencionou o fato de que "danos morais coletivos" não pareciam ser um 
conceito preciso. Ele afirmou que há uma cultura de vingança no Brasil, em que os órgãos públicos processam empresas privadas com base em uma falsa ideia de imperialismo econômico. Em sua opinião, há um mito generalizado de que as empresas privadas sempre tentam maximizar os lucros fornecendo níveis mínimos de serviço. Segundo ele, danos punitivos são uma imitação perigosa de um conceito estrangeiro que pode acabar arruinando negócios e levar à falência de empresas privadas.

Ironicamente, no entanto, ele admitiu que os danos punitivos não eram excessivamente altos para as empresas privadas. Como uma questão prática, não tinham sido impostas sanções econômicas impostas à sua empresa devido a ações coletivas consumeristas. Isso não quer dizer que não houve consequências internas. Pelo contrário, sempre que uma ação coletiva é ajuizada, o departamento jurídico da empresa está preocupado com a possível condenação, a publicidade negativa e os riscos econômicos inerentes. A aversão ao risco de sofrer danos punitivos afeta os negócios e as empresas privadas sempre investem mais recursos para evitar sanções econômicas. Em ao menos uma ocasião, a empresa não estava originalmente comprometida em investir em um determinado serviço e o investimento maciço naquele serviço só veio como resultado de uma ação coletiva. O jurídico explicou que esse caso era excepcional, já que negar os direitos dos consumidores e maximizar os lucros não faz parte da política da empresa. Segundo ele, o departamento jurídico da empresa tem poder de veto que pode ser superado apenas pelo CEO. Se os advogados demonstrarem que uma cláusula contratual ou uma determinada prática é ilegal, o seu aconselhamento jurídico não é submetido a um plano de negócios que avalia se os benefícios são superiores aos custos potenciais. No entanto, a análise de custos e benefícios é a lógica da empresa sempre que eles cometem uma ilegalidade imprevisível. Nesses casos, causados por práticas irregulares de mercado, mudanças doutrinárias e falhas regulatórias, geralmente é mais benéfico pagar indenizações aos poucos consumidores que processam judicialmente a empresa do que melhorar a qualidade de seus serviços.

A maioria dos entrevistados está preocupada com a possibilidade de que o sistema crie incentivos para litígios frívolos e condenações irracionais. No entanto, todos os atores jurídicos elogiaram o sistema brasileiro de tutela coletiva de direitos, uma vez que as empresas privadas não devem pagar indenizações por danos punitivos a consumidores individuais, mas a um Fundo de Proteção de Direitos do Consumidor. ${ }^{28}$ Todos consideram essa solução jurídica uma alternativa interessante ao modelo americano de justiça civil, no qual os danos punitivos podem beneficiar um litigante individual. Um dos juízes afirmou que tal sistema encoraja os consumidores a sofrer danos e, eventualmente, tomar medidas para maximizar as consequências negativas dos erros cometidos por uma empresa, simplesmente para ter direito a uma recompensa maior. Esse sistema não apenas estimula a má-fé, mas também produz mais externalidades e a sociedade teria de arcar com custos sociais excessivos.

Vale ressaltar que a maioria dos entrevistados se referiu a casos americanos emblemáticos para expressar sua preocupação com sanções econômicas exageradas.

${ }^{28}$ Artigo 13 da Lei Federal no $7.347 / 85$. 
Cinco entrevistados mencionaram o caso do café McDonald's como um exemplo a não ser seguido pelos tribunais brasileiros. Três entrevistados comentaram vagamente que os Estados Unidos eram conhecidos por recompensas monetárias excessivas, mas não afirmaram nada sobre esses casos que eram apenas evidências anedóticas para eles. Um promotor de justiça também se referiu ao caso do café McDonald's e ao caso Pinto, mas elogiou o sistema estadunidense de justiça civil e sua capacidade de influenciar as rotinas operacionais e a tomada de decisões dentro de empresas privadas. $\mathrm{O}$ caso Pinto também foi mencionado por um juiz como um exemplo da importância dos danos punitivos. Uma juíza criticou não apenas os excessos dos Estados Unidos, mas também a apatia da França. Segundo ela, o consumidor francês é muitas vezes desprotegido e as empresas privadas sempre alegam que não são responsáveis por qualquer dano causado ao consumidor. Na opinião dela, o sistema brasileiro é o melhor, pois é o mais equilibrado.

Com exceção dos advogados privados, todos os atores jurídicos defenderam a existência de indenizações por danos punitivos no Brasil e afirmaram que a falta de indenizações punitivas quase sempre produzirá incentivos econômicos para que empresas privadas violem o CDC. O jurídico do banco argumentou que as instituições financeiras estão muito preocupadas com sua imagem e com publicidade negativa e danos punitivos são, portanto, desnecessários. $O$ jurídico da empresa de telecomunicações alegou que os danos punitivos seriam internalizados como custos, e os consumidores teriam que pagar por eles através de preços mais altos ou serviços de menor qualidade.

Ambos os iuízes mencionaram que a punicão excessiva pode ser preiudicial aos consumidores. Ambos destacaram o fato de que a imposicão de danos punitivos envolve uma equacão complexa e que a sancão econômica deve ser proporcional. De acordo com um iuiz, a punicão não deveria arruinar os negócios, nem desencorajar os investidores e deve ser do interesse dos consumidores ao invés de prejudicá-los.

Indagados sobre os fatores que devem ser levados em consideração para fixar o valor dos danos punitivos, os entrevistados mencionaram: (i) porte da empresa; (ii) quantidade de dano causado às vítimas; (iii) quantidade de lucro obtido devido a irregularidade; (iv) capacidade para prevenir mais irregularidades; (v) grau e severidade de má conduta. Não foi possível concluir a partir de suas respostas se esses fatores são hierárquicos. Como disse um dos promotores de justiça, esses parâmetros devem vir de um grande número de julgamentos práticos. No entanto, os tribunais raramente - ou nunca - examinaram os critérios para a quantificação de danos punitivos em uma ação coletiva consumerista. Além disso, os estudiosos brasileiros não os discutem..$^{29}$

É claro, portanto, que a falta de indenizacões por danos punitivos aiuda a explicar o fenômeno da ilicitude lucrativa, uma vez aue os "danos morais coletivos" permanecem simplesmente como parte do "direito nos livros" em vez do "direito em

\footnotetext{
${ }^{29}$ Recentemente publicamos um texto sobre o tema: FORTES, Pedro R. B.; OLIVEIRA, Pedro Oliveira. A Quantificação do Dano Moral Coletivo. In: ROSENVALD, Nelson Rosenvald; NETO, Felipe Teixeira (org.). Dano Moral Coletivo. Indaiatuba: Editora Foco, 2018.
} 
acão" ("law on the books" versus "law in action"). A próxima secão mostrará aue o sistema de ações coletivas consumeristas também carece de outras sanções econômicas.

\section{Falta de outras sanções econômicas}

Além dos danos punitivos, as empresas privadas podem sofrer outras consequências econômicas como resultado da ação coletiva de proteção dos consumidores. Por exemplo, um banco ou empresa de telecomunicações pode ser condenado a reembolsar uma tarifa ilegal que foi cobrada de seus clientes. Pesquisadores americanos frequentemente criticam os acordos de ação coletiva devido à tentação de colusão entre advogados da classe e da empresa e ao fato de que as vítimas podem receber menos dinheiro ou mesmo cupons de desconto, o que exigirá novas compras na empresa do réu. No Brasil, no entanto, o cenário é ainda pior em termos de recompensas econômicas, uma vez que se espera que os clientes individuais sejam proativos para receber qualquer indenização. $\mathrm{O}$ sistema brasileiro de tutela coletiva espera que cada consumidor contrate um advogado e participe individualmente da ação coletiva para exigir sua parcela de indenização. De acordo com a análise quantitativa, houve apenas 21 condenações definitivas no período intermediário e nenhuma delas resultou em indenização para vítimas individuais.

Ambos os iuízes estavam cientes desse fenômeno e afirmaram que os consumidores individuais quase nunca se beneficiam de uma acão coletiva. Um deles até disse que não se lembrava de uma única compensacão individual em seus muitos anos na Vara Empresarial da Capital. O outro iuiz se referiu ao pagamento de indenizacão de um consumidor como um fenômeno extremamente raro. Sua opinião é coerente com a análise quantitativa e foi compartilhada por todos os outros atores jurídicos.

O iurídico do banco explicou que o sistema brasileiro de tutela coletiva de direitos ainda está amadurecendo. Nos primeiros anos, as acões coletivas consumeristas eram extremamente raras e não estava claro se o CDC também regulava as instituicões financeiras. Segundo ele, apenas algumas acões coletivas contra os bancos receberam sentencas definitivas e agora estão prontas para serem aplicadas e cumpridas. Nesses casos, os consumidores individuais geralmente só aiuizavam suas acões individuais contra bancos ou simplesmente não seguiam os iulgamentos de acões coletivas. Portanto, uma vez que haia uma sentenca definitiva, as vítimas individuais não são informadas ou já terão sido compensadas por outros meios.

O iurídico da empresa de telecomunicacões acrescentou que não apenas a iustica civil brasileira é lenta, mas muitas acões coletivas têm como obieto o pagamento de valores pequenos a título de danos compensatórios. Apenas alguns clientes demandam o pagamento desses danos compensatórios por meio de processos iudiciais individuais, nos quais a empresa pode negociar acordos individuais e pagar danos extra-patrimoniais mais elevados. Apenas uma pequena percentagem de clientes aiuíza as acões individuais e. em última análise, a empresa pode se beneficiar do fato de que a massa de consumidores não busca ser indenizada e nem é compensada como um todo. Como informado pelo jurídico, sua empresa de telecomunicações ainda não 
tinha tido que pagar qualquer tipo de sanção econômica devido a uma ação coletiva consumerista.

Os demandantes também confirmaram que a compensação individual por meio de ações coletivas é rara no Brasil. Todos os entrevistados concordaram que um sistema menos burocrático seria muito mais eficaz. Todos eles consideraram que a necessidade de contratar um advogado para se habilitar e exigir compensação era um forte obstáculo à indenização individual nas ações coletivas. No entanto, ambos os juízes ficaram intrigados com a ideia de abolir essa formalidade e não podiam conceber um sistema diferente. Alguns demandantes sugeriram a possibilidade de conceber medidas administrativas para fazer cumprir as decisões judiciais em um sistema híbrido que conciliaria a independência dos juízes com os custos mais baixos e com maior nível de informação das agências reguladoras e de outros órgãos administrativos.

A maioria dos atores jurídicos considera que as medidas liminares são o método mais eficaz de proteção ao consumidor. Ambos os juízes afirmaram que suas ordens são quase sempre seguidas e, se não, fixariam e cobrariam multas mais altas. Ambos os advogados privados concordaram que suas empresas não desafiam ordens judiciais, mesmo que discordem da decisão. A menos que uma ordem judicial seja inviável, eles afirmam que nunca irão desobedecer. Os autores concordam que as liminares podem ser muito eficazes, mas reclamam que, às vezes, os juízes relutam em cobrar multas. De qualquer forma, todos concordam que as sanções econômicas podem vir mais facilmente quando uma empresa privada desafia uma ordem judicial do que de outra forma.

\section{Enfrentando a ilicitude lucrativa}

Conforme as entrevistas revelam, as empresas brasileiras podem se beneficiar de infringir a lei e de violar os direitos do consumidor. $O$ que pode ser feito para impedir suas transgressões e para se eliminar o fenômeno da lucrativa ilegalidade?

O jurídico do banco argumentou que o diálogo entre empresas, agências reguladoras e demandantes de ações coletivas é necessário. Segundo ele, os produtos e serviços financeiros devem obter a aprovação prévia dos departamentos de defesa do consumidor, a fim de evitar novas irregularidades. Instituições financeiras são frequentemente responsáveis porque o CDC não é claro.

O jurídico da empresa de telecomunicações alegou que mais ações coletivas são necessárias, uma vez que causam impacto interno real no negócio. Além disso, ele afirmou que medidas imediatas que afetam o lucro são as mais eficazes. Por exemplo, se a empresa não está executando um determinado serviço corretamente, proibir a empresa de contratar novos clientes para esse serviço é a maneira mais eficaz de forçar investimentos imediatos. Além disso, a publicidade negativa na mídia também é extremamente eficaz para evitar novas irregularidades. Por fim, ele acrescentou que os CEOs temem muito mais a responsabilidade pessoal do que os danos punitivos. Portanto, as liminares e sentenças seriam mais eficazes se impusessem sanções econômicas aos CEOs e, por fim, proibissem que eles dirigissem uma empresa por um 
determinado período de tempo. Danos punitivos não estão impondo sanções aos CEOs; eles estão punindo acionistas ou consumidores.

Uma iuíza também considerou que a desconsideracão da personalidade iurídica seria um meio eficaz de impedir a ilicitude lucrativa. Segundo ela, não há uma única fórmula, mas muitos instrumentos diferentes que deveriam ser usados com maior rapidez e frequência: ordens liminares; danos punitivos; proibicão de servicos; recall de produtos; e apreensão de bens. Ela também destacou a importância da mídia e sugeriu que as empresas devem ter a obrigacão de publicar o resumo de uma condenacão definitiva, para que os consumidores individuais possam estar cientes de que têm direito a uma indenizacão. O outro iuiz acredita que os tribunais brasileiros devem desenvolver uma cultura de imposição de multas e outras sanções econômicas, como indenizações por danos punitivos.

Todos os promotores de justiça, o advogado da Comissão de Defesa do Consumidor da ALERJ e o defensor público consideraram que os danos punitivos são uma forma eficaz de evitar novas irregularidades e eliminar o fenômeno da ilicitude lucrativa. Um dos promotores sugeriu que as ações coletivas devem ter prioridade sobre os outros casos, devido ao seu impacto sobre vários indivíduos. O outro promotor acrescentou que o sistema de justiça civil deve usar novos canais de tecnologia da informação para transmitir ações coletivas. Outro promotor enfatizou a responsabilidade pessoal dos CEOs e a desconsideração da personalidade jurídica como os instrumentos mais eficazes para evitar novas irregularidades. O advogado da Comissão elogiou as liminares como a ferramenta mais eficaz para eliminar a ilicitude lucrativa. Finalmente, o defensor público sugeriu que os ativos das empresas proporcionais ao dano coletivo devem ser bloqueados sempre que as empresas forem acusadas de prejudicar os direitos do consumidor, de modo que não se beneficiem desses recursos durante o litígio.

A pesquisa empírica demonstra, portanto, que o sistema deve ser reformado com o desenvolvimento de mecanismos mais eficazes de aplicacão do direito e sancões econômicas adequadas para evitar novas irreqularidades. A próxima secão fornecerá um estudo de caso mostrando como as empresas podem violar a lei, uma vez que não têm desincentivos apropriados para cumprir a legislação.

\section{POR QUE AS EMPRESAS PODEM VIOLAR A LEI?}

Como um estudo de caso, um exemplo de transgressão coletiva revela os incentivos que as empresas brasileiras tinham para infringir a lei. A C-TV, uma empresa de telecomunicações, decidiu cobrar $\mathrm{R} \$ 10,00$ (dez reais), por mês de todos os consumidores que pagavam suas contas mediante pagamento junto aos bancos. No entanto, esta tarifa de pagamento bancário (ou "tarifa de boleto bancário") é proibida pelas agências reguladoras. Tanto o Banco Central do Brasil (doravante BACEN) quanto a Agência Nacional de Telecomunicações (doravante ANATEL) definiram que a aceitação de pagamentos é uma função bancária típica, que pode não estar sujeita à cobrança de qualquer tarifa. Afinal, como os bancos lucram com empréstimos de dinheiro e altas taxas de juros, as instituições financeiras já se beneficiam do acúmulo de recursos monetários resultantes desses pagamentos. Além disso, o pagamento em 
si não é um serviço que agrega valor ao consumidor, já que ela se beneficia da radiodifusão, mas não do pagamento bancário. Portanto, de acordo com a legislação e leis brasileiras, a cobrança de tarifas de pagamento bancário (ou "tarifa de boleto bancário") é uma conduta ilegal e, consequentemente, proibida.

Por que então a C-TV cobraria essas tarifas ilegais? O estudo do caso revela que a C-TV possuía incentivos econômicos para fazer a cobrança ainda que fosse proibida pelo BACEN e pela ANATEL. Como os tribunais brasileiros raramente condenam as empresas a pagar indenizações por danos punitivos e a maioria das condenações não é efetivamente cumprida, a C-TV possuía fortes incentivos econômicos para violar a lei. Se a empresa cumprisse com o CDC e com a regulamentação federal, não haveria qualquer retorno para a C-TV ou para seus clientes. Em um cenário de sub-dissuasão, no qual uma empresa é condenada, mas não forçada a compensar ou pagar danos extra patrimoniais, a C-TV teria um pagamento de $\mathrm{R} \$ 10$ por mês para cada consumidor que pagar suas contas. através do sistema bancário. Por outro lado, cada um desses consumidores perdeu $\mathrm{R} \$ 10$ por mês e não recuperou o dinheiro. Supondo que houvesse uma aplicação perfeita do direito, tanto a empresa quanto os consumidores não teriam nenhum retorno financeiro, mas esse não é um cenário realista. Pelo contrário, as empresas quase nunca compensam totalmente os danos causados coletivamente a seus clientes nas ações coletivas brasileiras. Como discutido anteriormente, a aplicação ineficaz resulta em sub-dissuasão, dissuasão imperfeita e execução ineficaz, promovendo ciclos de ilicitude lucrativa.

A premissa tradicional na academia brasileira era de que não haveria diferença nos payoffs entre (i) conformidade com a lei e (ii) ilegalidade seguida de condenação e compensação patrimonial. De acordo com Teori Zavascki, os danos são limitados por serem essencialmente os recursos monetários necessários para compensar totalmente os erros cometidos. Assim, não se deveria admitir a imposição de danos extrapatrimoniais (como os "danos morais coletivos") para punir as empresas por violações dos direitos dos consumidores em massa. Seu argumento segue a ideia de que tais danos punitivos representariam custos excessivos que seriam internalizados pelas empresas e transferidos para seus acionistas ou consumidores. Em outras palavras, danos punitivos nunca deveriam ser admitidos no sistema legal brasileiro devido às consequências econômicas prejudiciais. ${ }^{30}$

No entanto, a tese acadêmica referida acima - que denominarei "hipótese 1" - não se relaciona com a realidade. A análise empírica demonstra que muitos outros elementos analíticos devem ser incluídos neste contexto. A análise deve envolver a avaliação dos custos de transação, a circunstância repetitiva do jogo processual e o cenário de execução imperfeita. Não se deve ignorar, por exemplo, que a aplicação da lei por meio de ação coletiva implicaria necessariamente custos processuais que podemos estimar em $\mathrm{R} \$ 2,00$ ( $20 \%$ do valor da causa, segundo a tradição brasileira). Por uma questão de experiência, quando uma empresa é condenada, muitas vezes há perda de reputação e uma redução de valor da empresa que podemos estimar em $\mathrm{R} \$$ 1. Também devemos considerar os custos do litígio que afetam o retorno dos

30 ZAVASCKI, Teori A. Processo coletivo: tutela de direitos coletivos e tutela coletiva de direitos. São Paulo: RT, $4^{\text {a }}$ ed. 2009 , p. 40-43. 
consumidores. No sistema jurídico brasileiro, os consumidores não precisam cobrir as despesas com ações judiciais. Não obstante, o tempo corrói o valor de sua compensação monetária. As taxas de juros legais são de $12 \%$ ao ano, inferiores aos investimentos e taxas de empréstimo, que é uma perda monetária que poderíamos estimar como equivalente a $\mathrm{R} \$ 2,00 .{ }^{31}$

Figura 6 - Hipótese 1. Sem custos de transação e assumindo aplicação perfeita do direito, não faria diferença se uma empresa cumpre com a lei ou se ela viola a lei e é condenada e obrigada a indenizar os consumidores

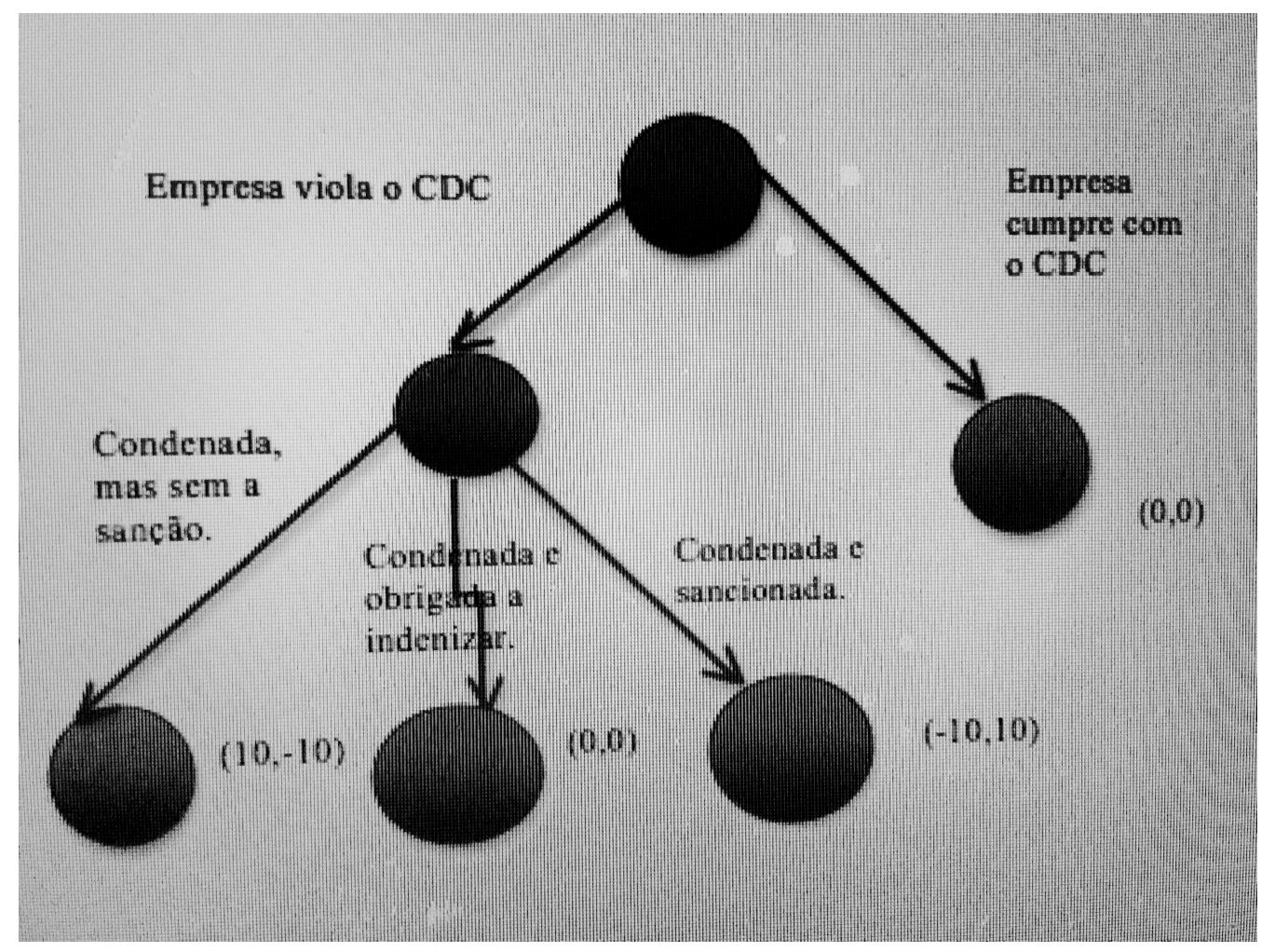

Fonte: elaborado pelo autor.

Este contexto sócio-jurídico mais sofisticado e relacionado com a realidade, irei denominar "hipótese 2". Podemos ver que o resultado ótimo - no qual as empresas e os consumidores não têm payoffs e a riqueza da sociedade não é minimizada - exige que as empresas cumpram o CDC. Além da avaliação dos custos de transação, devemos considerar também o cenário de execução imperfeita e a circunstância

${ }^{31}$ De acordo com Baird, Gertner, e Picker, "we shall assume that a player values a payoff in a future period less than a payoff in the future period. We account for this by introducing a discount factor, the amount by which the value of a payoff in the next period must be adjusted to reflect its value in the present period. If we have a discount factor of $\delta$, the present value of one dollar earned in the subsequent period is $\delta$ dollars". BAIRD, Douglas G.; GERTNER, Robert H.; PICKER, Randal C. Game Theory and the Law. Harvard University Press, 2003, p. 168. 
repetitiva do jogo processual. ${ }^{32}$ As empresas privadas são frequentemente jogadores repetidos ("repeat players", conforme a terminologia estadunidense) em ações coletivas consumeristas. Em particular, as empresas de telecomunicações estão sempre entre as principais empresas no topo da lista de reclamações dos consumidores. ${ }^{33} \mathrm{~A}$ experiência como litigante revela às empresas um cenário de execução imperfeita, no qual os danos punitivos raramente eram impostos e em que, mesmo condenada, uma empresa não era forçada a indenizar individualmente todos os danos dos consumidores. Neste cenário, as empresas tinham incentivos econômicos claros para tornar violar a lei.

Figura 7 - Hipótese 2. Com custos de transação e aplicação imperfeita do direito, torna-se claro que o sistema jurídico cria incentivos econômicos para as empresas violarem a lei e produzem externalidades que são negativas para o bem-estar social.

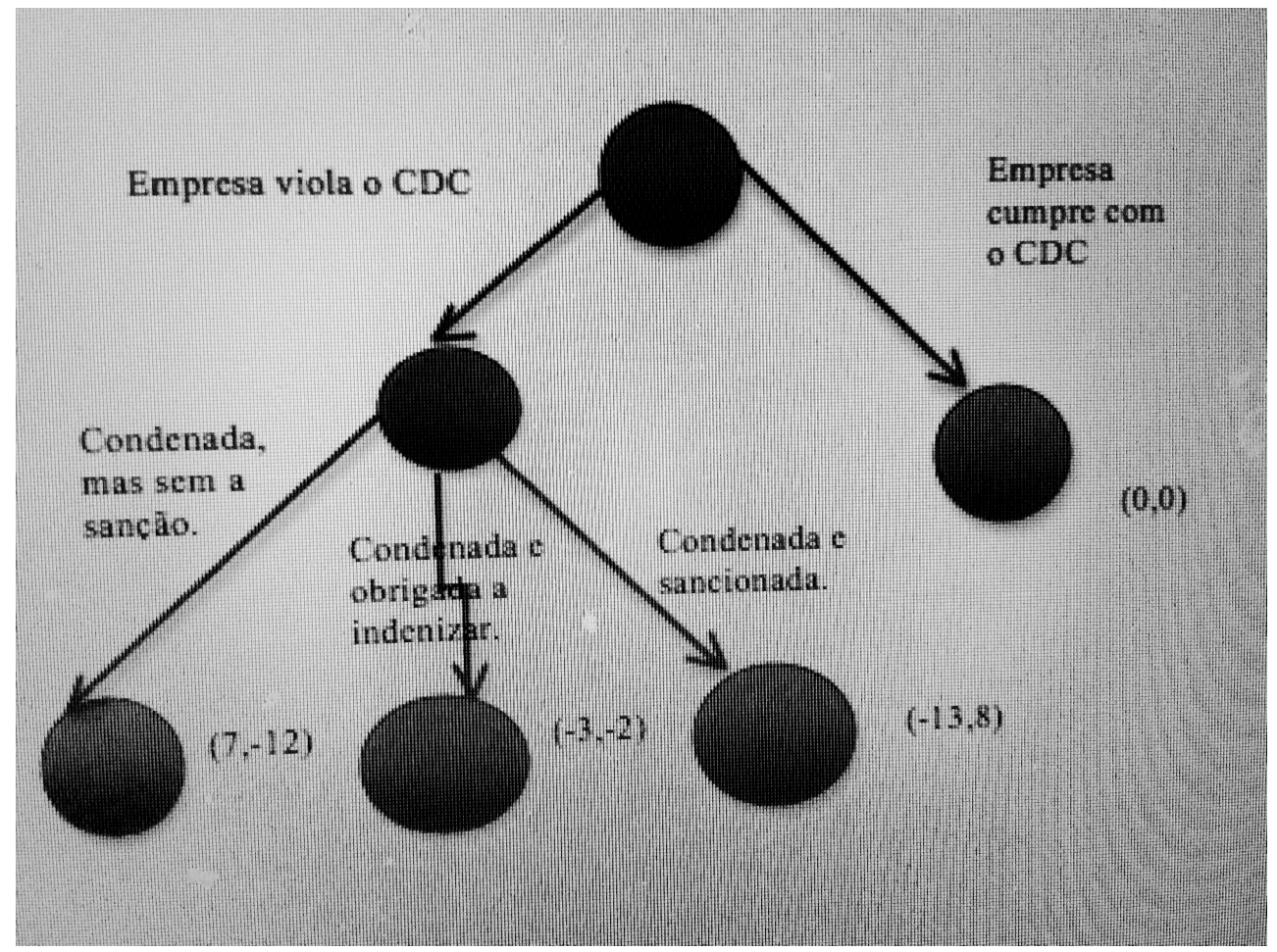

Fonte: elaborado pelo autor.

No cenário A, a C-TV enfrentaria riscos mínimos de ser condenada a pagar indenizações por dano moral coletivo de caráter punitivo e riscos mínimos de ser forçada a pagar indenização compensatória aos consumidores lesados. A C-TV é susceptível de ser condenada, mas sem que seja obrigada ao cumprimento efetivo e à execução perfeita da sentença. Estimando as probabilidades a partir dos dados

32 Ibid, p. 159-187.

${ }^{33}$ Veja, por exemplo, http://www.procon.sp.gov.br/pdf/acs_ranking_2010.pdf.

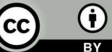


coletados para esta pesquisa, ${ }^{34}$ parece haver uma chance de $1 \%$ de pagar indenizações por dano moral coletivo de caráter punitivo; 3\% de chance de pagar indenização compensatória aos consumidores lesados; e 96\% de chance de não pagar nada, exceto custos processuais e eventual perda de reputação. Em um cenário tão realista, o retorno esperado para a C-TV é de $\mathrm{R} \$ 6,5 .^{35}$

Vamos agora considerar um cenário diferente $B$, no qual uma reforma jurídica melhore os remédios judiciais e uma quantidade significativa de sentenças esteja agora sob o efeito dessa reforma e atenda aos objetivos da efetiva aplicação e cumprimento da decisão judicial. No entanto, o foco da reforma legal é limitado à aplicação de indenizações compensatórias aos consumidores lesados, uma vez que a cultura jurídica ainda rejeita os danos punitivos. Assim, o legislador proíbe todas as formas de danos extra-patrimoniais em ações coletivas, independentemente da denominação dada ("danos morais coletivos", "danos punitivos" ou qualquer outro nome). Estimando as probabilidades, vamos supor que existe uma chance de $0 \%$ de pagar indenizações por danos punitivos; $50 \%$ de chance de pagar indenização compensatória individual; $50 \%$ de chance de não pagar nada, exceto custos processuais e perda de reputação. Em tal cenário, o retorno esperado para a C-TV é de R $\$ 2 .{ }^{36}$

Consideremos finalmente o cenário $\mathrm{C}$, no qual a reforma jurídica não apenas melhora os remédios judiciais, mas também estabelece um regime de critérios equilibrados e claros para impor danos punitivos às empresas privadas. Assim, a legislatura tem como objetivo a dissuasão ótima e afirma-se que os danos punitivos devem ser impostos quando a dissuasão seria inadequada devido à possibilidade de que os transgressores coletivos escapassem à sua responsabilidade. Estimando as probabilidades, vamos supor que haja $20 \%$ de chance de pagar indenizações por danos punitivos; $40 \%$ de chance de pagar indenização por compensação individual; $40 \%$ de chance de não pagar nada, exceto custos processuais e perda de reputação. Nesse cenário, o retorno esperado para a C-TV é de $\mathrm{R} \$-1 .^{37}$

Refletindo sobre esses três cenários diferentes, podemos entender por que as empresas brasileiras têm incentivos para continuar violar o direito do consumidor. No cenário $\mathrm{A}$, a aplicação imperfeita fornece excelentes incentivos econômicos para a CTV cobrar a tarifa ilegal. Mesmo com custos processuais e perda de reputação, dada a pequena probabilidade de enfrentar sanções econômicas, a recompensa esperada é de $\mathrm{R} \$$ 6,5. O cenário A parece ser semelhante ao atual cenário brasileiro, dada a rejeição

\footnotetext{
34 Sou grato a um revisor anônimo da JOxCSLS que não apenas elogiou este artigo, mas também sugeriu que, em vez de uma hipotése imaginada, eu deveria fundamentar meu cenário realista em dados empíricos coletados por meio de entrevistas e análises de casos. Segui seu conselho, mas - de maneira conservadora - presumi que três casos pendentes levariam a condenações definitivas de empresas a pagar indenizações punitivas. No entanto, a probabilidade de uma condenação na amostra analisada foi quase nula e a quantidade de recompensas monetárias nas poucas condenações foi muito baixa. A estimativa de $3 \%$ para indenização compensatória também veio da análise de casos pendentes em que as empresas pudessem ter que reconhecer um crédito para os consumidores em uma relação contratual de longo prazo.

$35(0.01) \times(-13)+(0.03) \times(-3)+(0.96) \times(7)=-0.13-0.09+6.72=6.5$.

$36(0.0) \times(-13)+(0.5) \times(-3)+(0.5) \times(7)=-1.5+3.5=2$

$37(0.2) \times(-13)+(0.4) \times(-3)+(0.4) \times(7)=-2.6-1.2+2.8=-1$
} 
aos danos punitivos pelos tribunais e a aplicação muito baixa. Em um cenário B hipotético, a falta de danos punitivos ainda cria um ambiente de sanções econômicas limitadas para a C-TV. Portanto, embora a reforma jurídica tenha melhorado a aplicação da decisão judicial e reduzido os incentivos econômicos para violar a lei, a recompensa esperada ainda é de $\mathrm{R} \$ 2$. As empresas privadas ainda são incentivadas a violar o CDC. Em um cenário alternativo $C$, a reforma jurídica melhora os remédios existentes e estabelece um regime de indenizações por danos punitivos, oferecendo aos tribunais ferramentas eficazes para impor sanções econômicas como consequência das transgressões coletivas dos direitos dos consumidores. Nesse cenário, a recompensa esperada é de $\mathrm{R} \$$ - 1 e a empresa privada provavelmente não infringirá a lei.

Esse estudo de caso e a observacão empírica das acões coletivas consumeristas fornecem fatores explicativos para o fenômeno da ilicitude lucrativa.

\section{CONCLUSÃO}

Muitos acadêmicos criticam os critérios para aplicar indenizações de caráter punitivo nos Estados Unidos. Joni Hersch e W. Kip Viscusi, por exemplo, compararam as decisões tomadas pelos júris e pelos juízes, concluindo que as recompensas dadas pelo júri são altamente imprevisíveis e não relacionadas à indenização por danos compensatórios em contraste com as decisões judiciais. ${ }^{38}$ Cass Sunstein também coordenou pesquisa empírica que apontou para a necessidade de uma reforma de danos punitivos para eliminar condenações erráticas e extremamente caras. ${ }^{39}$

Por outro lado, alguns estudos chegaram a conclusões contrárias. Theodore Eisenberg, Jeffrev I. Rachlinskv e Martin T. Wells não identificaram um padrão imprevisível de recompensa por danos punitivos ou um padrão chocante de incoerência e iniustica. ${ }^{40}$ Em pesquisa empírica anterior, Theodore Eisenberg, Iohn Goerdt, Brian Ostrom, David Rottman e Martin T. Wells iá haviam demonstrado a previsibilidade dos danos punitivos e a correlação entre as recompensas fixadas pelo júri e os danos compensatórios. ${ }^{41-42}$

${ }^{38}$ HERSCH, Joni; VISCUSI, W. Kip. Punitive damages: how juries and judges perform. The Journal of Legal Studies, v. 33, n. 1, 2004, p. 01-36.

39 SUNSTEIN, Cass R. et al. Punitive damages: how juries decide. Chicago: Chicago Press, 2002. Ver também SUNSTEIN, Cass R.; KAHNEMAN, Daniel; SCHKADE, David. Assessing punitive damages (with notes on cognition and valuation in law). In: SUNSTEIN, Cass R. Behavioral Law and Economics (Ed.). Cambridge University Press, 2000.

40 EISENBERG, Theodore; RACHLINSKY, Jeffrey J.; WELLS, Martin T. Reconciling experimental incoherence with real-world coherence in punitive damages. Stanford Law Review, v. 54, n. 6, 2002, p. 1239-1271.

${ }^{41}$ EISENBERG, Theodore et al. The predictability of punitive damages. The Journal of Legal Studies, v. 26, n. S2, 1997, p. 623-661.

42 Veja, ainda, as decisões da Suprema Corte dos Estados Unidos com a imposição de limites constitucionais aos danos punitivos: BMW of North America v. Gore, 517 U.S. (1996); State Farm Mutual Automobile Insurance Co v. Campbell, 538 U.S. 408, 417 (2003); Exxon Shipping Co v. Baker, 554 U.S. 471 (2008). Veja, ainda, FISHER, Jeffrey L. The Exxon Valdez case and regularizing punishment. Alaska Law Review, v. 26, n. 1, p. 1-46, 2009. 
A análise da cultura iurídica brasileira e a amostra de acões coletivas consumeristas no Rio de Ianeiro também é relevante para refletir sobre o sistema iudiciário americano. A falta de sancões econômicas gera incentivos para as empresas brasileiras infringirem a lei. Portanto, tanto a Suprema Corte dos Estados Unidos, quanto o STI não devem eliminar os danos punitivos ou os "danos morais coletivos" e nem devem impor limitações que impeçam os tribunais de sancionar empresas de forma efetiva.

O número extremamente limitado de condenacões para pagamentos de indenizacões por danos punitivos tinha impacto direto nos acordos estabelecidos entre promotores de iustica e empresas privadas. Ouase todos os acordos no Rio de Ianeiro até abril de 2011 não impuseram sancões econômicas às empresas privadas porque o iulgamento desses processos coletivos provavelmente não resultaria em sancões econômicas. A correlacão entre acordos e indenizacões por danos punitivos também foi identificada em pesquisa empírica pelo Professor de Stanford Mitchell Polinskv em seu estudo sobre o sistema americano - a diferenca sendo que nos Estados Unidos os danos punitivos induziram as empresas a fazer um acordo e a resolver o processo coletivo. ${ }^{43}$

Como um iuiz apontou, as empresas são mais propensas a quebrar a lei em mercados menos competitivos. As empresas de telecomunicacões e instituicões financeiras operam em mercados limitados e podem estabelecer barreiras para os clientes deixarem seus contratos. Cláusulas de fidelidade, custos de transacão e outras restricões podem limitar a capacidade do consumidor de ter uma nova conta bancária em um banco diferente ou deixar uma companhia telefônica para seu concorrente. Por outro lado, as empresas são menos propensas a quebrar a lei em mercados mais competitivos.

Além disso, tanto o jurídico do banco quanto o jurídico da empresa de telecomunicações afirmaram eloquentemente que suas empresas não avaliam os possíveis riscos econômicos da violação de direitos do consumidor sob uma análise de custo-benefício antes de tomar decisões. Por outro lado, foi admitido que tal análise é feita depois que uma ação coletiva consumerista é ajuizada. Proponho uma interpretação contra-intuitiva de suas declarações. Ao contrário da ideia de senso comum, a inexistência de uma análise de custo-benefício não é evidência de que essas empresas respeitem os direitos dos consumidores e não violem a lei para obter lucros ilegais. A falta de análise de custo-benefício é uma evidência clara de que as empresas privadas brasileiras não esperam ser punidas devido a violações maciças dos direitos dos consumidores. A menos que os tribunais levem as sanções econômicas a sério e punam as empresas privadas por seus erros, as empresas brasileiras tornarão a violar o direito do consumidor.

Uma última observação se faz necessária no sentido de esclarecer que o cenário já se transformou desde 2011 até o presente. Em primeiro lugar, a jurisprudência dos Tribunais Superiores se consolidou quanto ao reconhecimento da existência dos danos

43 POLINSKY, A. Mitchell. Are punitive damages really insignificant, predictable and rational? A comment on Eisenberg et al. The Journal of Legal Studies, v. 26, 1997, p. 663-677. 
morais coletivos de caráter punitivo no Brasil, ${ }^{44}$ sendo admitido dentre nós o seu caráter de pena civil ${ }^{45}$ e tendo ocorrido condenações por dano moral coletivo ao longo da última década. Em segundo lugar, ocorreu desde 2011 uma mudança no cenário descrito com a celebração de vários acordos entre os atores coletivos e as empresas com cláusulas de pagamento de compensação financeira (por dano moral coletivo) e várias execuções coletivas a título de recuperação fluída ('fluid recovery') da lesão cometida contra os consumidores individuais que não se habilitaram para receber sua indenização. ${ }^{46}$ Apesar de o presente texto ainda não ter sido publicado em português até o presente momento, algumas de suas ideias já circularam, tendo sido utilizadas na academia e na experiência forense. ${ }^{47}$ Contudo, o fenômeno da ilicitude lucrativa persiste como problema complexo e desafio da tutela coletiva de direitos. A publicação da presente pesquisa pretende estimular o aprofundamento do tema entre nós, bem como uma reflexão sobre a necessidade de adoção de medidas práticas para a imposição efetiva e eficiente de sanções econômicas a empresas e executivos de maneira a se prevenir o enriquecimento injustificado resultante das transgressões coletivas sem a imposição da devida pena civil aos transgressores.

44 SOARES, Flaviana Rampazzo. O percurso do "dano moral coletivo" na jurisprudência do Superior Tribunal de Justiça. In: ROSENVALD, Nelson; NETO, Felipe Teixeira (org.). Dano Moral Coletivo. Indaiatuba: Editora Foco, 2018, p. 73-95.

45 ROSENVALD, Nelson. O dano moral coletivo como uma pena civil. In: ROSENVALD, Nelson; NETO, Felipe Teixeira (org.). Dano Moral Coletivo. Indaiatuba: Editora Foco, 2018, p. 97-127.

${ }^{46}$ Agradeço a Júlio Machado pelo feedback de que a análise empírica desse texto era um retrato de duas décadas e de que teriam ocorrido mudanças significativas desde a condução das entrevistas originais em 2011, como bem ressaltado nesse parágrafo que incorporou seus comentários ao artigo.

${ }^{47}$ Mesmo antes de sua publicação, a pesquisa teve circulação em meios acadêmicos e profissionais, tendo seus dados sido utilizados no âmbito do MPRJ como fundamento para a decisão de criação da 5a Promotoria de Justiça de Tutela Coletiva de Defesa do Consumidor da Capital. Além disso, o conceito de ilicitude lucrativa foi adotado em petições, recursos e em outros documentos com o objetivo de transformação do cenário identificado em 2011. Finalmente, mesmo antes de sua publicação, a pesquisa e o conceito de ilicitude lucrativa foram citados em publicações, tais como, por exemplo, DA SILVA FILHO, Osny. Punitive (and) Pain-and-Suffering Damages in Brazil. Law and Social Economics. New York, Palgrave Macmillan, 2015, p. 183-207. 